\title{
YOKSULLUĞUN KÜRESEL BOYUTLARI
}

\author{
Mesut Çakır* \\ Sansel Aldemir ${ }^{* *}$
}

\section{$\ddot{O}_{z e t}{ }^{* * *}$}

Dünya üzerinde giderek artan ve yoğunlaşan yoksulluk olgusu, insanlığın en önemli sorunlarinin başında gelmektedir. Ekonomik gelişmenin yanistra, sosyal kalkınmanin sağlanması bu olgunun en aza indirilmesi ile gerçekleşebilecektir.

Bu amaçla çalışmada, yoksulluğa ilişkin temel yaklaşım, ölçütler verildikten sonra yoksulluğun nedenleri az gelişmis, gelişmekte olan ve gelişmiş ülkeler için ayrı ayr verilmiş ve küreselleşmenin yoksulluk olgusuna etkileri tartı̧̧lmıştır. Daha sonra, küresel yoksulluğun genel görüntüsü ortaya konularak, buna yönelik çözüm önerileri geliştirilmiştir.

\section{Giriş}

Yoksulluk, ekonomik bir kavram olmanın ötesinde, insan potansiyelinin değişik biçimlerde boşa harcanması anlamına da gelmektedir. Dünyada 1.3 milyar insan yoksulluk sınırının altında yaşamaktadır. Ülkelerin gelişmişlik derecelerine bakılmaksızın önemli boyutlara ulaşan yoksul kitleler,

\footnotetext{
*Yrd. Doç. Dr. Adnan Menderes Üniversitesi Nazilli İ̈BF İktisat Bölümü

** Araş. Gör.Adnan Menderes Üniversitesi Nazilli İIBBF Maliye Bölümü.

${ }^{* * *}$ For the summary in English, see the end page of the article.
} 
Birleşmiş Milletler ve Dünya Bankası gibi bir çok uluslararası kuruluşu da harekete geçirmiştir.

$\mathrm{Bu}$ çalışmada, yoksulluğa ilişkin kavram ve ölçütler hakkında bilgi verildikten sonra, iktisat ekollerinin yoksulluğa yaklaşımları incelenerek; azgelişmiş, gelişmekte olan ve gelişmiş ülkelerde yoksulluğun nedenleri ve boyutları arasındaki farklılıklar ele alınacaktır. Aynı zamanda, 1970'lerde temeli atılan 1980'li yıllarda ise özellikle gelişmekte olan ülkelerde uygulamaya konulan finansal serbestleşme politikaları çerçevesinde başlayan "küreselleşme" sürecinin yoksulluk ile ilişkisi de incelenecektir.

\section{Yoksulluk Kavramı, Yaklaşımları ve Ölçütleri}

Yoksulluğun nasıl tanımlanması gerektiği kolayca yanıtlanabilecek bir soru değildir. Genel olarak yoksulluk; veri bir toplumsal yaşam standardının mutlak veya göreli olarak minumum düzeyinin altında kalan nüfusun karş1 karşıya kaldığı bir olgu olarak değerlendirilebilir. Boyutları anlamında yoksulluk ise, sürdürülebilir bir geçim sağlamaya yetecek gelirin olmaması, üretim kaynaklarından mahrumiyet, açllk ve yetersiz beslenme, sağlık, eğitim ve diğer hizmetlere ulaşamama, hastalık ve buna bağlı ölümlerin artması, evsizlik ve yetersiz barınma koşulları, güvenli olmayan çevre koşulları gibi kıstasların yanısıra sosyal ayırım ve dışlanmışlığa maruz kalmak, karar verme süreçlerine, sosyal ve kültürel yaşama katılımdan yoksun olmak demektir (Akçar, 1998: 202). Yoksulluk üzerine ülke içinde veya ülkeler arası karşılaştırma yapılabilmesi için, toplam nüfus içerisinde kimlerin "yoksul" olarak nitelendirilmesi gerektiği belirginleştirilmelidir. $\mathrm{Bu}$ konuda genellikle üç farklı tanıma referans verilmektedir. Bunlar; mutlak, göreceli ve öznel yoksulluktur.

\subsection{Yoksulluğa İlişkin Yaklaşımlar}

1.1.1. Mutlak Yoksulluk: Mutlak yoksulluk, bir insanın günlük kalori gereksinimine göre hesaplanmaktadır. Bu miktar, ülkelerin sosyo-ekonomik yapıları ve coğrafi koşullarına göre değişebilmektedir. Yukarıda belirtildiği gibi bu miktar gelişmiş ülkelerde 3390 kalori, gelişmekte olan ülkelerde 2480 kalori ve azgelişmiş olan ülkelerde 2070 kalori olarak hesap edilmiştir. 
$\mathrm{Bu}$ miktarlar, ülkenin o yıl içindeki yiyecek fiyatlarının ortalamaları itibari ile paraya çevrilir ve yoksulluk sınırı olarak alınır. (Dansuk, 1997:20).

Yoksulluk oranı olarak mutlak yoksulluğun kullanılması, sadece gıdanın dikkate alınmasından dolayı bir eksiklik yaratabilir. Bunun yanında, toplumdaki gıda harcamalarına göre en düşük yaşam standardının ortaya çıkarılması ise mutlak yoksulluğun yararı olarak ifade edilebilir.

1.1.2. Göreceli Yoksulluk: Göreli yoksulluk, toplumdaki ortalama refah seviyesinin belirli bir oranının aşağısında kalan kişi grubunu ifade eder. Yoksulluk çizgisinin belirlenmesinde birey ve hane halkının ortalama refah seviyesi dikkate alınır. Bu noktada refah ölçüsü olarak, gelir veya tüketim seviyesi seçilebilir. Özellikle gelişmiş ülkelerde yapılan çalışmaların çoğunda refah ölçüsü olarak toplam gelirin alındığı görülmektedir.

Toplam geliri belli bir miktarın (yoksulluk çizgisi) altında olan birey veya hanehalkı yoksul olarak nitelendirilir. Göreli yoksulluk kavramında, yoksulluk çizgisini belirleme aşamasında yapılan, ortalama gelir seviyesinin (ortanca veya aritmetik ortalama) belli bir yüzdesini standart \% 50'sini almaktır. Yoksulluk araştırmalarında genellikle aritmetik ortalama yerine ortanca (gelirler en küçükten en büyüğe sıraya dizildiğinde tam ortadaki gelirin değeri) tercih edilir (TUSİAD, 2000: 104).

Göreceli yoksulluğun en önemli yararı, gelir dağılımı eşitsizliğini en açık biçimde vermesidir.

1.1.3. Öznel Yoksulluk: Bu yaklaşım önerdiği yöntem bakımından diğerlerinden farklılık gösterir. $\mathrm{Bu}$ çerçevede yoksulluğun, toplumun belirlediği minumum bir yaşam seviyesi olarak kabul edilmesinden hareketle, büyük ölçekli anketler uygulayarak toplumun bu konudaki görüşünü belirlemek yoluyla yoksulluk çizgisinin ortaya çıkarılması hedeflenmektedir.

Öznel yoksulluğu belirlemek amacıyla yapılan anketlerde farklı yöntemler kullanılır. Deneklere; yoksul olmamak, iyi bir gelire sahip olmak gibi bazı özel hedeflere ulaşabilmek için yeterli olduğunu düşündükleri gelir miktarı sorulur. Bu yöntem "Leyden Yaklaşımı" olarak bilinir. (Atkinson'dan aktaran: TUSİAD, 2000: 104). Anket sonuçlarından hareketle kritik bir refah seviyesi seçilip ona karşılık gelen gelir seviyesi yoksulluk çizgisi olarak kabul edilir. 


\subsection{Yoksulluk Ölçütleri}

1.2.1. Yoksulluk Oranı (Head- Count İndex) : Yoksulluk çizgisinin altında kalan nüfus yüzdesi "yoksulluk oranı" olarak adlandırılır. Genel olarak yoksulluk oranı, ekonomik gelişmenin olduğu dönemlerde düşer, ekonomik büyümenin olmadığı dönemlerde ise artar (Tregorthen, 1996: 404).

Yoksulluk oranı endeksinin, en önemli eksikliği, yoksulluğun şiddeti konusunda herhangi bir anlam ifade etmemesidir. Gelirin yoksullar arasındaki dağılımına duyarlı olmadığı gibi, yoksulluk çizgisi altında bulunan kişilerin gelirlerindeki azalmalara, bu kişiler arasındaki gelir transferlerine ve yoksullardan yoksul olmayanlara yapilan transferlere de duyarsızdır.

1.2.2. Yoksulluk Aralığı (Boşluğu): Yoksulluk aralığı; yoksulluk çizgisi altına düşen tüm yoksul kişilerin gelirlerinin toplamıdır. Diğer bir anlatımla yoksulluk boşluğu, yoksul olan herkesin yoksulluk çizgisine çıkarılması için gereken para miktarını temsil etmektedir (http:// www.cbpp.org/index.html). $\mathrm{Bu}$ endeks de, yoksulluk oranı endeksi gibi yoksullar arasındaki gelir dağılımı dengesizliklerine duyarsızdır.

1.2.3. Foster-Greer-Thorbecke Endeksi: Bu endeks, eşitsizlik katsayısı ve yoksulluk oranı arasındaki ilişkileri belirleyen etmenleri ortaya çıkarır.

1.2.4. Sen Endeksi: Bu ölçütte, yoksulluk oranı ve eşitsizlik katsayısı arasındaki ilişki dikkate alınmaktadır. En çok bilinen mutlak yoksulluk ölçütlerinden olan Sen Endeksi; yoksul sayılarını, yoksulluğun derecelerini ve yoksullar arasındaki gelir dağılımını göstermesi bakımından önemlidir.

\section{3. İktisat Ekollerindeki Yoksulluk}

\subsection{Klasik ve Neoklasik İktisatın Yoksulluğa Bakışı}

Klasik iktisatçılarda, adaletli gelir dağılımının nasıl olması gerektiği konusunda belirgin bir fikir birliği yoktur. Bu demek değildir ki, klasik iktisatçılar ahlaklı değillerdir. Her ikisi de büyük ahlak filozofu olan Smith 
ve Hume, yardımseverliği ve iyiliği temel fazilet (meziyet) olarak kabul ederler ama bunun nadir olduğuna ilişkin de not düşmüşlerdir. Smith'in büyük çalışması"'Ulusların Zenginliği"'nde zenginliği ilerleten bir piyasa ekonomisinin bu meziyetlere bağlı olmadığı gösterilmektedir. Bu sadece büyük miktarda kişinin birarada ve anlaşma ile yaşamalarını gerektirir. Aralarında kişisel bağlar olmasa bile, "adaletin yasaları" olduğu sürece şiddet olmayacaktır. Ticari toplumlarda çok çalışma, basiret, tasarruf ve itimat gibi bazı meziyet olarak nitelendirilen olgular artış gösterir. Bir firma, diğerlerine göre kazanç sağlarsa alturizme daha az önem gösterir. Ancak genel başarının artması ile birlikte, daha düşük seviyedeki meziyetler istemeyerek yapılır hale gelir. Dolayısıyla, toplum sonuçta maneviyatsız (immoral) olacaktır. Bu durumda iyi bir hükümet, adaletin kanunlarını uygulamaya koyarak özgür değişimi ve barışçll rekabeti garanti altına alan doğal özgürlüklerin gelişmesini sağlayan politikalar yoluyla zenginliği artıracaktır. Ahlaksal (moral) ilerleme ise, hükümet dışı kurumlara birakılacaktır. Ama Smith'den Friedman ve Hayek'e kadar uzanan klasik liberaller, toplumun ya da devletin toplam yoksulluğu hafifletme yollarını araması gerektiğini kabul etmişlerdir (Deepaklal and Myınt, 1996: 38).

Ceşitli hizmetkarlar, emekçiler ve zenaatçiler her büyük siyasi topluluğun büyük kısmını oluştururlar. Toplumun bu büyük bölümünün durumunu iyileştiren şey hiçbir zaman toplumun bütünü açısından bir olumsuzluk olarak değerlendirilemez. Üyelerinin büyük bir bölümü yoksul ve perişan durumda olan hiçbir toplum elbette, gelişkin ve mutlu olamaz (Smith, 1997:73)

Klasik iktisadın öncülerinden Adam Smith'e göre, yoksullara ilişkin olarak yapılacak yardımların hiçbir yararı olmadığı gibi, bu yardımlar üretimi de sınırlandıracaktır. Çünkü yardım alan yoksullar, tembelliğe alışmakta ve iş aramaktan vazgeçmektedirler. Smith, o dönemde İngiltere'de yürürlükte olan "Yoksulluk Yasaları"na da bu yüzden karşı çıkmaktadır.

Neo-klasik yaklaşım, bölüşüm sorununu iki ayrı düzeyde formüle etmiştir. Bireyler ve faktörler arası bölüşüm. Gelirin bireyler arasındaki bölüşümü, üretim faktörlerinin bireyler arasındaki dağılımına ve faktör fiyatlarına bağlıdır. Sınıfsal bölüşüm söz konusu olmadığı gibi bireyler arasındaki bölüşümü belirleyen temel unsur olan üretim faktörlerinin dağılımı sorunu da bir kenara atılmaktadır (Akyüz, 1980.95). 
Neo-Klasik kuram, temel varsayım ve kanunlarından hareketle bir dizi yeni iliş̧ üretir. Bu ilişkilerden biri de $\mathrm{MP}(\mathrm{L})=\mathrm{w} / \mathrm{p}$ denkliğidir. İlişki, denge koşullarında üretimin zorunlu bir sonucu olarak ortaya çıkar ve Neo-Klasik üretimde kar maksimizasyonu sağlamanın koşullarından biridir. Burada w/p terimi işgücüne ödenen reel ücreti, $\mathrm{MP}(\mathrm{L})$ ise işgücünün üretime katkısını gösterir. $\mathrm{Bu}$ eşitlik, Neo-Klasik kuramda, işgücünün denge koşullarında alması gereken ücretin üretime ne kadarlık katkı yaptığı ile ilgili olduğunu gösterir. Başka bir deyişle, emeğin sahip olduğu değişim değeri ne kadarlık bir üretim katkısı yaptığı ile yani emeğin verimliliği ile doğru orantılıdır. Bu öneri, bir yanıyla da emeğin kapitalist sistemde zorunlu olarak sömürüldüğunü söyleyen Marx'a bir yanıttır. Neo-Klasik kuram, emeğin de sermaye gibi gelirden üretime katkısıyla oranlı bir pay aldığını söyleyerek denge koşullarındaki kapitalist sistemin adil bir sistem olduğunu savunmaktadır (Erol, 1997: 224).

Geleneksel olarak Neo-klasikler sosyal refah devletinin küçültülüp gücünün kırılması ve onun sosyal programlarına olan bağımlılığın azaltılması üzerinde durmaktadırlar. Onlara göre yoksulluğun en önemli nedeni aşırı cömert programlar olarak belirginleşmektedir. Çünkü, bu tür programlar insanları yoksulluk içinde yaşamaya özendirmektedir. Bu düşüncenin en önde gelen savunucusu Charles Murray'a (1984) göre yoksullukla savaş için oluşturulmuş olan sosyal programlar, yoksulluğu azaltıp ortadan kaldırmak yerine artırmaktadır. Yazar, yoksulların çalı̧̧mak yerine bu programlardan elde ettikleri gelirlerle yaşamlarını sürdürmeyi yeğlediğini, bunun da yoksulluğun sürekli hale gelmesine ve artmasına neden olduğunu ileri sürmektedir (Sallan Gül ve Gül, 1996,:9).

Drucker ise, yoksullara yönelik politikalar için şu değerlendirmeyi yapmaktadır:

"20. yy'da yoksulların sosyal koşullarını değiştirmek amactyla çok daha büyük miktarlarda devlet parası harcadık. Elde edilen sonuçlar ise, hemen hemen hiçbir fark göstermeden hayal kirıci olmuştur. Kimi alanlarda yoksulların içinde bulunduğu koşullar kötüleşmiştir. Aslında güçlü kanttlar göstererek, Amerika'daki yoksullara özellikle de yoksul siyahlara yapılan sosyal yardım miktarı arttıkça,bu insanların daha yoksul, daha çaresiz, daha zararli duruma düstüklerini söylemek mümkündür -ve bu söylenmiştir deAmerika'daki sosyal yardım harcamaları bağımlılığı teşvik etmektedir. Güç kazandırmak yerine felce uğratmaktadır" (Drucker, 1996:71). 
Lawrance C. Mead ise yoksulluğun nedenini sınıfdışı üyelerinin yanlış bireysel tercihlerinin toplam ürünü olduğunu, üyelerinin "tercih ehliyetsizliğine" bağlamaktadır. Yoksullar yalnızca çalışma hayatının avantajlarını değerlendirme ehliyetinden yoksundurlar; "çalışmama" 1 çalıșmanın üstüne koyarak yanlış tercihler yapmaktadırlar. Yoksulluk kültürünün özü, psikologların etkisizlik diye adlandırdıklan, kendi hayatını kontrol edebilme yetersizliği gibi görünmektedir (Bauman, 1999: 106). Bu görüşe göre yoksulluk, yoksulların öğrendiği bir "yaşam biçimi”"dir. Yoksulluk kültürü sadece düşük geliri içermez, bunun yanında aldırmazlık, duygusuzluk, vazgeçmişlik ve sorumsuzluğu da içerir. Yoksulluk kültürü; oto-kontrol, çok çalışma ve plan yapıp gelecek için tasarruf etme eksikliğini teşvik eder. Aynı zamanda, aile dayanaksızlığını da teşvik eder. Şimdiki memnuniyet, şu andaki yöneliş, geleceğe yönelişin yerine geçmiştir. Bütün bu tutumları, yoksulların kendileri için hazır olan firsat avantajlarını sağlamayı engellemektedir. Nakit ödemeler bile, sabit fikirli bu yoksulların yaşam tarzlarını çok değiştirmeyecektir. Bu teoriye göre, sağlanan ek gelir, hızlı bir şekilde gereksiz ve önemsiz şeylere harcanacaktır (Dye, 1992: 123).

Neoklasikler, yoksulluğun tedavisi için şu önermeleri yapmaktadırlar (Akalın, 1981:283):

- Öncelikle faktör donatımını artırmak ve bunun bireyler arasındaki dağılımını düzeltmek gerekir.

- İnsanın kalitesini ve üretken kapasitesini belirleyen beşeri sermayenin kalitesi ve miktan artırılmalıdır.

- Bütün bunlardan sonra yine de yoksul kalan muhtaçlara da sosyal yardımlar yapılmalıdır.

Neo-Klasik yaklaşımda yoksul insanlar, herhangi bir meziyete ve şansa sahip olmayan kişiler olarak kabul edilmektedir. Kişiler şu an maddi açıdan yoksul ve dezavantajlı durumda olabilirler ama bu kişiler girişken nitelikte ise ve şansları da yardım ederse, konumlarını değiştirip, sınıf değiştirebilirler. Dolayısıyla Neo-Klasik yaklaşımda ve bu anlamda kapitalizmde herkes için umut yaratacak örnekler mevcuttur. Neo-klasikler, gelir dağılımı konusunu ahlaki bir boyuta indirmekte ve böylelikle bu konuyu ekonomik analizlerinin dişında tutmaktadırlar. 


\subsection{Marksist İktisatın Yoksulluğa Bakışı}

Marx, klasik emek-değer teorisini kabul eder ve buradan artı-değer teorisini türetir. Ancak, klasiklerde emekçinin oluşturduğu artı-değer istihdamın gerekçesi olurken, Marx'ta sömürünün kaynağı olur. Bir malı değerli kılan o malın üretiminde kullanılan emektir. Emeğin kendi ücreti dışında oluşturduğu artı-değer kapitalist sermaye birikiminin kaynağıdır. Eğer bir üretim sonucu oluşan hasılayı onu oluşturan faktör alacak olsa, hasılanın tamamını emeğin alması gerekir ki, gerçekte böyle olmaz (Demir, 1997:41).

Marksist tartışma; yoksulluğun, yönetici sınıfin kendi çıkarlarına hizmet etmesi nedeniyle ortaya çıtığını iddia eder. Yoksullar, toplumun pis işlerini yapmak için varlardır. Fiziksel olarak pis ve tehlikeli, geçici, ölümlü ve hakkından az para verilen işlerde çalışırlar. Yoksul; kimsenin istemediği, kullanılmış, eski ve kusurlu malları satın alır ve ayrıca yanlış olarak değerlendirilen toplumsal normları desteklemekle suçlanır. Örneğin yoksul, tembel olarak nitelendirilir, çünkü toplum değerleri çok çalışan, endüstrileşmiş insanlardan yanadır (Dye, 1992:124).

Marx, çalışma olanağından yoksun olanların bir kısmının sefalete mahkum olduğunu düşünmektedir. $\mathrm{Bu}$ işsizliğin, kapitalist ekonominin gelişme koşullarından biri olduğunu ileri sürmekte ve bunun nedenini, kapitalistlerin ekonomik koşullar uygun olduğu zamanlarda karşılarında "yedek sanayi ordusu" nu görmek istemelerine bağlamaktadır. Marx'a göre mülkiyetin ihlali eğer bir hırsızlıksa, özel mülkiyetin kendisi de bir hırsızlıktır.

Büyük sanayi rejimine bağlı proletaryanın ekonomik önemi arttığı ölçüde bu işsizler ordusunun önemi de artmakta, dolayısıyla da sefalet iş̧̧i sınıfında büsbütün yaygınlaşmaktadır. Marx' in vardığ1 genel sonuç, "ïcretlerin haddi yüksek ya da düşük olsun, sermaye biriktikçe emekçinin yaşama koşullarının her gün biraz daha kötüleşeceğı’’dir (Denis, 1974:453).

Diğer taraftan Marx,, görecel yoksullaşma teorisine de değinmiştir. Buna göre, toplumdaki bütün sınıfların geliri artsa bile, değişik sınıfların gelirleri arasındaki göreceli farklar da o oranda artacaktır. Böylesi bir durum, zenginlik ve yoksulluk arasındaki karşıtlıkları daha da belirginleștirecektir. Toplam üretim arttıkça, ihtiyaç ve istekler de artacak; mutlak yoksulluk azalsa bile göreceli yoksulluk büyüyecektir. 
Eğer Marksist söylemi kabul edersek, kapitalist bir toplum kamu politikasını yoksulluğu muhafaza edecek şekilde biçimlendirecektir. Sosyal politikalar, yoksulluğu hafifletecek veya sona erdirecek şekilde biçimlendirilmeyecek ama daha çok yoksulları düzenleyecektir. Diğer bir anlatımla, sosyal politika; ayaklanmadan, şiddetten veya devrimden sakınacak şekilde biçimlendirilirse de yoksulluğun devamını garanti altına alacaktır (Dye, 1992:124).

Marksist görüşe göre, piyasa şartlarında sermaye burjuvanın elinde birikmeye başlar ve böylelikle yoksulluk ve sömürüde de artış görülür. Dolayısıyla, yoksulluğun azaltılması piyasa şartlarında olanaklı değildir. Bunu ancak devlet azaltabilir.

\subsection{Keynezyen İktisatın Yoksulluğa Bakışı}

Keynezyenler, kapitalizmde tam istihdam dengesini kendiliğinden kuracak mekanizmanın bulunmadığını ve dolayısıyla devletin bunun sağlanmasında maliye politikası önlemleriyle ekonomiye müdahale etmesi gerekliliğine inanmışlardır. Dolayısıyla, politika farklılıklan olsa da Keynezyenleri de kapitalizme inandıkları için "klasik" olarak nitelendirmek olasidir.

Gelirler arasındaki farkların giderilmesi, istihdam politikasının bir aracı olarak Keynes ve taraftarlarınca ileri sürülmektedir. Gelir farklılıklarının giderilmesi, tam istihdama ulaşmada bir araç olarak uygunluk arzetmektedir. Burada, ortalama tasarruf eğiliminin artan gelirle birlikte yükseldiği şartından hareket edilir. Kendilerine gelir aktarılanların tasarruf eğilimi bu yüzden yüksek gelirlilere nazaran daha azdır. Bu durumda az gelir alanın payı arttı̆gndan, gelir seviyesinin eşitlendirilmesiyle ortalama tüketim eğiliminin artmasına yol açılmaktadır. Böylece tüketim artışıyla nihayet toplam talep, üretim ve istihdam seviyesi yükselmektedir (Aksu, 1993:34).

Keynezyenlere göre, ciddi bir resesyon ve geniş ölçekli işsizlik, yoksulluk çizgisi altında yaşayan nüfus yüzdesini artırır. Bu görüş açısına göre, yoksulluğa karşı en etkili politika, ekonomik gelişmenin ve istihdam olanaklarının devamını temin etmektir. Tarihsel olarak yoksulluktaki en büyük düşüşler, refah zamanlarında ortaya çıkmıştır (Dye, 1992:123). 


\section{Azgelişmiş, Gelişmekte ve Gelişmiş Ülkelerde Yoksulluğun Nedenleri}

Yoksulluk, ekonomik olduğu kadar toplumsal bir olgu olarak da belirginlik kazanmaktadır. Bu çerçevede, her toplumda veya her ülke ekonomisinde yoksulluğun tarihsel ve ekonomik nedenleri farklıdır. Genel olarak azgelişmiş, gelişmekte olan ve gelişmiş ülke ekonomilerinde yoksulluğun boyutları ve şiddeti arasındaki farklılıklar, bu ülkelerde yoksulluğun nedenleri arasındaki farklılıklara bağlı olarak değişim göstermektedir.

\subsection{Azgelişmiş Ülkelerde Yoksulluğun Nedenleri ve Boyutları}

Yoksulluğun daha basit olduğu fakir ülkelerdeki refahın ölçümünde, gerçek yiyecek tüketimi ve korunumu tercih edilir. Ortaya çıkan ekonomik yoksulluk, hayatta kalmak veya yaşammı sürdürmek için çok az sayıda kaynağa sahip olma ile ölçülür. Bu çerçevede; yaşam beklentisi, genç yaştaki ölüm oranları, kamusal sağlık hizmetlerinin yokluğu, cehalet ve diğer temel yoksulluk ölçümleri ile sosyal dışlanmışlık gelire göre daha genel ve kolay bir ölçüm yöntemidir (Smeeding, 1997: 198).

3.1.1. Bölgesel, Etnik ve Siyasal Amaçlı Savaşlar: Özellikle bir çok Afrika ülkesinde görülen etnik kökenli anlaşmazlıklar, en büyük yoksullaşma mekanizmalarıdır.

\subsubsection{Hammadde ve Malzeme Üretimine Yönelik Üretim} Yapısından Yoksunluk: $\mathrm{Bu}$ tür ülkeler, temel tüketim ve ara malları üretecek üretim yapılarına sahip olmadıkları için, asgari ihtiyaçlarını dahi toplumsal bazda sağlayabilmekten uzaktırlar. Genellikle bu tip ülkelerin, toprak verimliliği düşük ve her türlü çevresel bozulmalara açık bir yapıları vardir.

\subsection{Gelişmekte Olan Ülkelerde Yoksulluğun Nedenleri ve Boyutları}

3.2.1. Yoksulluk Kısır Döngüsü: Kişi başına gelir düşüklüğü, düşük gelir ve daimi bir hal alan düşük verimlilik şartlarındaki fakir ülkelerin 
tasarruf ve yatırım yapmalarını oldukça güçleştirir. Üstelik yüksek nüfus artışı, kişi başına reel gelirdeki artışları kolaylıkla absorbe edebilir ve bu suretle yoksulluk kısır döngüsünün kırılması olasılığının ortadan kaldırabilir (McConnal and Brue; 1996: 461). Her ne kadar ekonomik büyüme oranları, birçok gelişmekte olan ülkede 1990'lar boyunca artış gösterdiyse de nüfusun büyük bir kısmı aşın yoksulluk içinde yaşamaya devam etmektedir. Yaşam beklentisindeki artış, okullaşma oranı, yetişkin okur-yazar oranı ve bebek ölümlerindeki azalış gibi konularda ilerleme kaydedilse de, bu süreç oldukça yavaştır ve gelişmekte olan ülkeler ile endüstrileşmiş ülkeler arasındaki açık oldukça büyük kalmaya devam etmektedir (Ahmed and Bredenkamp, 2000: $10)$.

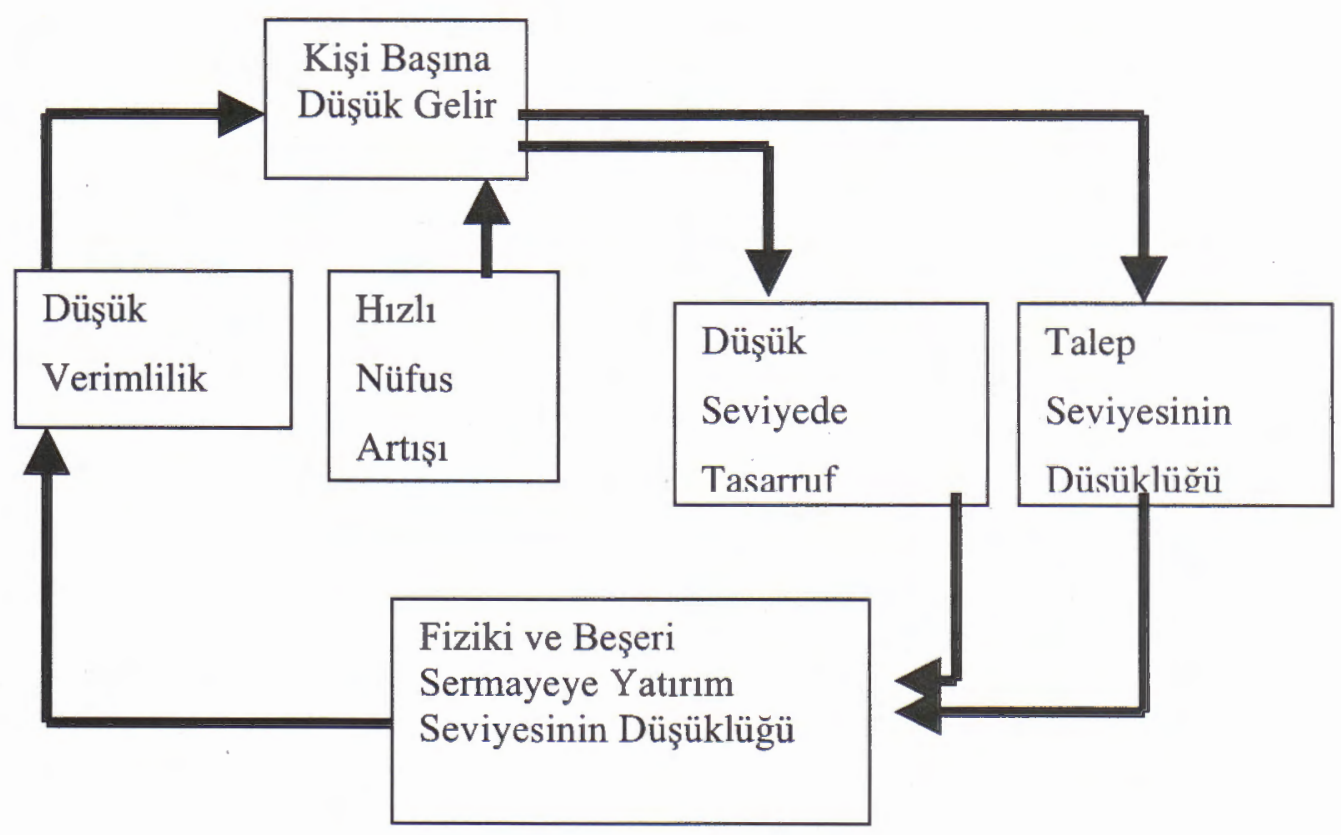

\subsubsection{Sermaye Birikim Modellerindeki Değişim ve IMF Programlanı}

Özellikle 1980'lerden itibaren artan küreselleşme eğilimlerine paralel olarak bir çok gelişmekte olan ülke IMF ve Dünya Bankası'nın da 
baskılarıyla finansal serbestleşme sürecine girerek, ithal ikameci büyüme modelinden ihracata dayalı büyüme stratejilerine ağırlık vermişlerdir.

Çoğu gelişmekte olan ülkede bu strateji, milli gelir içinde ticari ve finans sermayesinin öneminin ve payının artması ile birlikte iç borçlanma aracılığı ile sermaye kesimine sürekli ve önemli miktarlarda bir gelir transferini de beraberinde getirmiştir.

\subsubsection{Bozuk Gelir Dağılımı}

Pek çok ülkede yapılan çalışmalarda yoksulluğun derecesi genellikle tüketime dayalı, kalori esaslı yoksulluk çizgisi yardımıyla ölçülmektedir. Burada yoksulluk ile eşitsizliği (inequality) birbirinden ayırmak gerekir. Çoğu kez aynı anlamda kullanılan yoksulluk ile eşitsizlik aslında farklıdır. Yoksulluk, toplumun belli bir kesiminin mutlak yaşam standardı ile ilgili iken; eşitsizlik, toplumda yer alan çeşitli hayat standartları arasındaki nisbi farklılıklarla ilgilidir. Bu durumda yoksullar arasında da bir gelir eşitsizliğinden söz etmek olanaklıdır (Dumanlı, 1996: 11).

Gelir dağılımı yapısı, bölüşüm ilişkilerini yansıtmaktadır. Diğer bir deyişle, gelir dağılımı bir ulusal ekonomi içinde üretilen mal ve hizmet değerlerinin, toplumsal kesimler arasındaki bölüşümünü gösterir. Bir ülkede yoksulluk toplumsal bir sorun olarak gündemdeyse o ülkenin gelir dağılımı mutlaka önemli ölçüde bozuktur. Çok yoksul ülkeler (örneğin Afrika ülkeleri) bu kuralın dışındadır. Yoksul ülkeler, zaten asgari ihtiyaçlarını karşılayabilecek üretim yapısından uzaktır. Gelişmekte olan ülkeler ise, temel tüketim ve ara malları üretebilmekte ve asgari ihtiyaçlarını toplumsal bazda genelde karşllayabilmektedir. Ancak bu ülkelerdeki sermaye birikimi modelleri, gelir dağılımı eşitsizliğini azaltmaktan uzaktır. Hatta bu modellerin, eşitsiz bölüşüm ilişkilerini bir gereklilik olarak kabul ettiğini söylemek daha gerçekçi görünmektedir (Dansuk, 1996:10).

Dünya Bankasının "Dünya Kalkınma Göstergeleri" 2000 raporuna göre, gelişmiş ülkelerin milli gelirleri 30 bin doları aşarken, bazı ülkelerin 100 dolarlarda kalması bir yana, zengin ülkelerde bile yardıma muhtaç insanların bulunması dünyadaki adaletsiz gelir dağılımını apaçık ortaya koymaktadır. Gelir dağılımının adaletli olup olmadığını saptayan gösterge olan "Gini Endeksi”' , bazı ülkelerde 20'lerde kalırken, bazılarında 60'ı aşmaktadır. 104 ülke arasında en adaletli gelir dağılımı Slovakya, Belarus, Avusturya, Japonya ve İskandinav ülkelerinde görülürken, Latin Amerika ve bazı Afrika 
ülkeleri son sıralarda yer almaktadır. Türkiye ise, ABD'ye benzer gelir dağılımı ile 70'inci sıradadır. Türkiye'nin Gini endeksi 41.5 iken, Amerika' da da bu endeks, benzer şekilde 40.8' dir (Radikal, 2000: 7).

Genel bir kural olarak, gelir dağılımının endüstrileşmiş ülkelerde (Japonya, Amerika gibi) az gelişmiş ülkelere göre (Honduras gibi) daha eşit olduğu söylenebilir. Gelir dağılımı aynı zamanda merkezi planlı ekonomilerde (Çin ve çökmeden önce Sovyetler Birliği'nde) kapitalist ülkelere göre daha eşittir. Bunun nedenleri arasında, servetin merkezi planlı ekonomilerde daha az yoğunlaşması ve ücret eşitsizliklerinin de daha az şiddette olması sayılabilir (Ragan, F.J. and Thomas, B.L; 1993: 886).

Yüksek gelir eşitsizliği, sadece tek başına kötü değildir, aynı zamanda yoksullukla da yakından ilişkilidir. Londana ve Szekely (1997) ile Osberg ve Xu (1997), yoksulluk seviyesi ve Gini katsayıları arasında aşikar bir şekilde pozitif bir ilişki olduğunu göstermişlerdir. İlk bahsedilen yüksekse, sonraki de yüksektir. Ravillion (1997), bu korelasyonu şöyle açıklamaktadır: İlk olarak, yüksek gelir eşitsizliği, büyüme oranını düşürebilir ve böylelikle yoksulluğu azaltmak daha zor hale gelir. İkincisi, benzer yüzdelerdeki bütün gelir seviyelerinin büyümeden kazanç sağladıklarını düşünsek bile, yüksek gelir eşitsizliği yoksulluğun azaltılmasına etki edecek ve böylelikle yoksullar gelir payının daha küçük bir kısmını elde ederek yoksulluğun azaltılması süreci yavaşlayacaktır (Martini, Pablo Rodas; 1999: 380).

$\mathrm{Bu}$ çerçevede ekonomik büyüme, gelir eşitsizliklerinin az olduğu ülkelerde eşitsizliğin yüksek olduğu ülkelere göre yoksulluğun azaltılmasında iki kat daha etkilidir. Aynı zamanda, büyüme sürecinde gelir dağılımının kötüleştiği ülkelerde, büyümenin yoksulluk üzerindeki etkileri de fazla değildir. Örneğin Bangladeş’te eğer eşitsizlik 1992 ve 1996 yılları arasında artmasayd, yoksulluk oranının $\% 7$ ile $\% 10$ oranında düşüş kaydedeceği tahmin ediliyordu (Lusting and Stern; 2000: 4).

3.2.3. Tüketici Toplum Modeli: Finansal serbestleşme politikalan sonucu çoğu gelişmekte olan ülkede, üretime değil, tüketime yönelik bir büyüme süreci yaşanmaktadır.

Bu çerçevede "yoksul olmak", bir zamanlar anlamını işsiz olma durumundan aldrysa, özellikle gelişmekte olan ve gelişmiş ülkelerde bugünkü anlaminı esas olarak yeterince tüketemiyor olma durumundan almaktadır. Tüketim toplumunda seri imalat, artık kitlesel emek gücüne 
gereksinim duymamakta ve bir zamanlar "yedek sanayi ordusu" olan yoksullar şimdi "defolu tüketiciler"e dönüştürülmektedir. Bu onları, toplumsal açıdan yararlı bir işlevden yoksun duruma sokuyor, toplumsal mevkiilerini ve iyileşme olasılıklarını geniş ölçüde etkileyen sonuçlar doğurmaktadır (Bauman, 1999:10).

\subsection{Gelişmiş Ülkelerde Yoksulluğun Nedenleri ve Boyutları}

Zengin ülkelerde ekonomik yoksulluğun ölçümü, ekonomik refah veya kaynakların ihtiyaçlara oranla hesaplanmasını içerir. Ekonomik refah, hane halkına ilişkin mevcut maddi kaynakları ifade eder. Bu kaynaklarla ilgili olan, tek başına maddi tüketim değildir ama daha çok topluma katılmak için hane halkı bireylerine verilen yeteneklerle de ilgilidir. Bu yetenekler, sosyal aktivitelere katılmayı içerir ve bu aktivitelere katılım, belirli bir seviyede refah üretir (Smeeding, 1997: 198).

Bütün gelişmiş ve zengin toplumlar sosyal olarak yüksek tabakadandır. Bazı bireylerin diğerlerine göre daha fazla kaynağı vardır. Özellikle sağlık, eğitim ve çocuk bakımı gibi sosyal hizmetlerin satın alımında piyasaya güvenin çok olduğu $\mathrm{ABD}$ gibi ülkelerde aile düzeni gibi kaynaklar sosyal katılım firsatlarına önemli ölçüde etki etmektedir. Parasal gelir bu tür toplumlarda merkezi kaynaktır. Ama hala önemli diğer bir kaynak çeşidi de sosyal sermayedir. Eğitim ve temel sağlık hizmetleri kabulü gibi parasal olmayan kazançların tümü insani yetenekleri artırmaya yöneliktir. Zengin toplumlarda aynı zamanda, bütün olarak topluma katılma yeteneklerinin sınırları ile refahı azaltan pek çok baskı da vardır. Örneğin; şiddet, coğrafi ve sosyal olarak izole edilmiş komşuluk, kamu eğitiminin düşük kalitesi ve kazanç ve meslek dengesizliği bir çok zengin ülkede ekonomik güvensizliği artırmaktadır (Smeeding, 1997: 197).

3.3.1. Düşük Verimlilik: Bazı iktisatçılar, yoksulluğun açıklanmasını "insani kalkınma teorisi"ne dayandırmaktadırlar. Yoksullar, ekonomik verimliliklerinin düşük olmasından dolayı yoksullardır. Serbest piyasa ekonomisinde işverene satacak beşeri sermayeye sahip değillerdir. (Bilgi, maharet, tahsil, çalışma alışkanlığı ve çalışabilirliği gibi) İşgücünden kaynaklanan eksiklik, yoksulluğun tek başına en önemli nedenidir. Yeterli eğitimi ve hüneri olmayanlar, aynı zamanda serbest işgücü piyasası için de 
bir dezavantajdır. Bu insanların işgüçlerinin talebi ve ücret oranları düşüktür, istihdamları genellikle geçicidir (Dye, 1992:123).

3.3.2. Ayırımcilık: Ekonomi teorileri tarafindan hesaplanmayan, yok sayılan ayırımcılık, yoksullukta önemli bir rol oynamaktadır. Gözlemler, siyahların beyazlara oranlara 3 katın üzerinde yoksulluğa maruz kaldığını göstermektedir. Her ne kadar siyahlar, aynı eğitim seviyesinde beyazlara göre daha az kazansalar da; siyahlar ve beyazlar arasındaki bazı gelir farklılıklarının nesiller arasındaki eğitim farklılıklarının bir ürünü olduğu da doğrudur (Dye, 1992: 124).

\section{Tablo 1: ABD'de Yoksulluk Eğilimi 1980-1990}

$\begin{array}{lrrrrrrr} & 1980 & 1984 & 1986 & 1987 & 1988 & 1989 & 1990 \\ \text { Nüfus (Milyon) } & 228 & 237 & 242 & 244 & 246 & 248 & 249 \\ \text { Yoksulluk (\%) } & 13 & 14,4 & 13,6 & 13,4 & 13,1 & 12,8 & 13,5 \\ \text { Beyazlar } & 10,2 & 11,5 & 11 & 10,4 & 10,1 & 10 & 10,7 \\ \text { Siyahlar } & 32,5 & 33,8 & 31,1 & 32,6 & 31,6 & 30,7 & 31,9 \\ \text { İspanyol Asıllılar } & 25,7 & 28,4 & 27,3 & 28,1 & 26,8 & 26,2 & 28,1 \\ \text { Yaşlılar } & 15,7 & 12,4 & 12,4 & 12,5 & 12 & 11,4 & \\ \text { Çocuklar } & 18,3 & 21,5 & 20,5 & 20,5 & 19,7 & 19,6 & 20,6 \\ \text { H.R. Kadın olan } & 36,7 & 38,4 & 38,3 & 38,3 & 37,2 & 32,2 & 33,4 \\ \text { Aileler } & & & & & & & \end{array}$

Kaynak: Hunger 1993'ten aktaran: Dumanl1, 1996: 55.

Yukarıdaki tabloda da görülebileceği gibi, Amerika'da siyahlar ve Íspanyol astlllar beyazlara göre ortalama olarak 3 kat fazla yoksulluk içindedir. Diğer bir dikkat çekici durum da, hane reisi kadın olan ailelerin yoksulluk olarak en kötü durumda olduklarını göstermektedir. Bu çerçevede, gelişmiş ülkelerde bile kadın yoksulluğunun önemli boyutlarda olduğu gözlenmektedir.

\section{Dünyada Küreselleşme Eğilimleri ve Yoksulluk Ílişkisi}

Bu bölümde, 1970'lerde temeli atılan 1980'li y1llarda ise, IMF ve Dünya Bankasının desteği ile birçok gelişmekte olan ülkede ve Türkiye'de dışsal 
finans üzerindeki kısıtlamaların kaldırılması ve piyasa mekanizması temelindeki politikalarla hızlı bir sürece giren küreselleşme eğiliminin, kamu politikalarındaki dönüşüm ile birlikte "yoksulluk" olgusunun toplum genelinde artmasına yol açıp açmadığı incelenecektir.

\subsection{Küreselleşme Sürecinde Kamu Politikalarındaki Dönüşüm ve Etkileri}

\subsubsection{Küreselleşmenin Siyasi Politikalar Üzerindeki Baskısı}

Küreselleşme ile birlikte ülke içi ve ülkeler arası büyüyen eşitsizlikleri beraberinde getiren ekonomik dönüşümdeki artış, aynı zamanda sosyal kalkınma sürecini de engellemiştir. Bir çok ülke, inanç ve kişinin kazanç sağlamalarına öncülük eden küreselleşme olgusu, 20. Yüzyılın sonralannda yayılmaya başlamıştır. Ancak, yoksul kişiler için sosyal dışlanmışlığı ve marjinalizasyonu da yoğunlaştırmış ve bazı ülkelerin yoksulluğu azaltma hedeflerine ulaşmalarını zorlaştırmıştır. Uluslararası borç yükleri, ticaret ve yatırım liberalizasyonu politikaları, mali sınırlamaların açılmasının büyük önemini ortaya koyan makro ekonomi politikalarının uygulanmasına ilişkin baskılar, resmi kalkınma hizmetlerinin aksatılması, sermaye hareketlerinin liberalizasyonu global ekonomide dengesizliği artırmış ve bu tür dönüşümler de ulusal ve yerel bütçeler üzerindeki bütün sınırlamaların kaldırılmasıyla ekonomik krizleri artırmıştır. Bütün bu fenomenler, bütçenin gelir ve dolayısıyla harcama kısmını zora sokmaktadır. Birçok ülke etkin olmayan vẻrgi toplama sistemini, gelirlerinin önemli bir bölümünü oluşturan tarifelere dayandırmıştır. Vergi indirimleri yoluyla yabancı yatırımları çekmek için artan rekabet ve tarifelerdeki azalış, hükümetlerin gelirlerini artırmalarını zorlaştırmıştır. Aynı zamanda, küreselleşme ile ilgili ekonomik istikrarsızlık, ekonomik güvensizliği de artırır. Dolayısıyla hükümetlerin, vatandaşlarını bu tür dengesizliklerden korumak için ek kaynaklarını harcamalarını gerektirir (Çağatay ve Diğ., 2000: 3). 


\subsubsection{IMF Politikalarının Etkileri}

"Eğer bir toplum, sinırlarl dahilinde bir ürün üretmek için 100 dolar harcadiğında bu para; malzemelere, işçilere ve diğer maliyetlere harcanacak ve bu harcamalarin yapıldiğl her alıci ekonomiye dahil olacaktır. Çarpan etkisine bağll olarak, 100 dolar değerindeki birincil üretim, çeşitli 100 dolarlarla ülkenin milli gelirine katkıda bulunabilecektir. Eğer para diğer bir ülke tarafindan harcanırsa, paranin sirkülasyonu ihracatçı ülke içinde olacaktır. Bu durum; ürün ihraç eden/mal ithal eden endüstrileşmiş ülkelerin neden zengin ve ürün ithal eden/mal ihraç eden gelişmemis ülkelerin neden fakir olduğunun bir nedenidir.

Gelişmis ülkeler, sermaye yoğun (bu yüzden ucuz) ürünlerini yüksek fiyatla satarak ve emek yoğun (bu yüzden pahall) ürünleri düsük fiyattan alarak zenginliklerini arturtrlar. Ticaretteki bu dengesizlik, zengin ile fakir arasındaki açığl genişletir. Zenginlik, tüketilebilecek ürünleri satar, üretim için gerekli malları değil."

(J.W. Smith, The World's Wasted Wealth 2 (Institute for Economic Democracy, 1994,pp.116,127,139).

Bir çok gelişmekte olan ülke, IMF ve Dünya Bankası gibi kurumların politikaları yüzünden borçlu durumdadır ve kısmi yoksulluk içindedir. $\mathrm{Bu}$ programlar pek çok yıldır gelişmekte olan ülkelerin zengin ülkelere bağımlılığını artırdığı yönünde ağır şekilde eleştirilmektedir. Dünya yüzünde gördügümüz büyük ölçüdeki yoksulluk, global piyasalar ve alışveriş pratiği ile geçmiş yıllarda bunun nasıl şekillendiği ile ilgilidir. Yabancı yatırımcılar açısından çekici kalmak için, IMF ve Dünya Bankası gibi kurumların aşağıda sayılan dayatmaları, gelişmekte olan ülkelerde artan yoksulluğa ve gelişmiş ülkelere bağımlılıklarının devamına yol açmaktadır.

- IMF'nin yapısal uyum politikaları, aynı zamanda bu ülkelerin borçlarını zamanında ödemek için yeterli parayı sağlamak açısından daha fazla ihracat yapmalidirlar.

- Ekonomik ve sosyal dengeyi sağlamadan ve hazır hale gelmeden önce global piyasalara girmeye zorlanan pek çok ülke vardır. 
- Batıdaki tüketicilerin favorileri olan kaynaklar, fakir bölgelerden bile daha ucuz hale gelmektedir.

- Hükümetler, parasal dengeyi korumak için, ihracatlarını artırmaya ihtiyaç duyarlar. (maliyetleri daha çok düşürmek ve kaynakları daha ucuz hale getirmek için).

- Hükümetler aynı zamanda şunları yapmalıdırlar:

- Daha az harcamalı

- Tüketimi kısmalı

- Finansal düzenlemeleri azaltmalı ya da ortadan

kaldırmalidir ("Causes of Poverty" in

www.globalıssues.org/TradeRelated/SAP.asp.)

Yapısal uyum, piyasa güçlerinin bilinçli ve kasıtlı manipülasyonları aracılığıyla gerçekleştirilen bir tür "ekonomik soykırım"a yol açmaktadır. Yapısal uyum programları dört milyardan fazla kişinin geçimini doğrudan etkilemektedir. Yapısal uyum programının hayata geçirilmesi, tekil borçlu ülkelerin büyük bir bölümünde, makro-ekonomik politikanın, güçlü mali ve siyasal çıkar grupları adına hareket eden IMF ve Dünya Bankası'nın doğrudan denetimi altında "uluslararasılaştırılmasını" sağlamaktadır. Söz konusu yeni ekonomik ve siyasal egemenlik biçimi piyasa güçlerinin görünüşte "tarafsız" etkileşimi aracılığıyla insanları ve hükümetleri ikinci plana itmektedir (Chossudovsky, 1999: 42).

Uluslararası finans kurumları, kredi veren ülkeler ve ticari bankalardan destek aramak zorunda kalan ülkelerde, devletin gücünün daha çok azaldığı görülmektedir. Sosyal ve ekonomik alanlarda karar verme gücünün önemli bir bölümü borç veren yabancılara devredilmiştir. Devlet finansmanının daralması, hükümetleri kamu hizmetlerini ve alt yapı yatırımlarını azaltmaya, kamu sektöründe istihdam ve ücret düzeylerini düşürmeye zorlamıştır. Ekonomide özelleştirmenin, Pazar oluşumunun, gayri resmileşmenin artışı ve ekonominin daha çok uluslararası bir nitelik kazanması, ekonomik faaliyetlerin artan oranda devletin doğrudan kontrolü dışına kaçtığ 1 anlamına gelmektedir. Devletin gücü; kalifiye memurların kaybı, sivil hizmet ahlakının bozulması, suç, şiddet ve hukuk dışılığın artışı ile daha da azalmaktadır (Prendergast, Renee and Steward, Frances; 1995: $63)$. 


\subsubsection{Küresel Yoksulluğun Genel Görüntüsü}

Gerek ülke içi gerek ülkeler arasındaki gelir eşitsizlikleri artarken, dünya yoksulluğuna ilişkin gerçekler gelir istatistiklerinin manipüle edilmesi yoluyla giderek daha fazla gizlenmektedir.

\section{Tablo 2: Uluslararası Yoksulluk Göstergeleri}

\begin{tabular}{|c|c|c|c|c|c|c|c|c|c|c|}
\hline & \multicolumn{6}{|c|}{ Kişi bașına ulusal ge Doğușta yașam ümidiOkur-yazar oranı } & \multicolumn{2}{|c|}{ HDI Indek Gini Kats. } & \multicolumn{2}{|c|}{ Yoksul Orani } \\
\hline & & & & & & & & & & \\
\hline & 1975 & 1987 & 1977 & 1987 & 1977 & 1985 & 1987 & 1985 & 1975 & 1987 \\
\hline Endonezy & 280 & 450 & 48 & 57 & 62 & 74 & 0,591 & 0,31 & 59 & 38,8 \\
\hline Pakistan & 299 & 350 & 51 & 58 & 21 & 30 & 0,433 & 0,36 & 43 & 29,56 \\
\hline Hindistan & 300 & 300 & 51 & 59 & 36 & 43 & 0,439 & 0,42 & 46 & 48,04 \\
\hline Sri Lanka & 471 & 400 & 69 & 71 & 75 & 87 & 0,789 & 0,45 & 14 & 24,11 \\
\hline Tayland & 584 & 850 & 61 & 61 & 82 & 91 & 0,783 & 0,47 & 32 & 29,62 \\
\hline Fas & 642 & 610 & 55 & 62 & 28 & 34 & 0,489 & & 26 & 37,08 \\
\hline Kolombiy: & 851 & 1240 & 62 & 65 & 81 & 88 & 0,801 & 0,45 & 19 & 41,93 \\
\hline Türkiye & 914 & 1210 & 61 & 65 & 60 & 74 & 0,751 & 0,43 & 14 & 15,56 \\
\hline Malezya & 1006 & 1810 & 67 & 70 & 60 & 74 & 0,8 & 0,48 & 12 & 27,05 \\
\hline Brezilya & 1136 & 2020 & 62 & 65 & 76 & 78 & 0,784 & 0,57 & 15 & 23,05 \\
\hline Yugoslav & 1701 & 2480 & 59 & $\overline{72}$ & 85 & 92 & 0,913 & & 5 & 23,7 \\
\hline
\end{tabular}

Kaynak: Dansuk, 1996: 44.

Yukarıdaki tablodan şu sonuçlar çıkarılabilir:

-Kişi başına ulusal gelir arttıkça, yoksulluk oranı düşmektedir. Fakat bu yeterli koşul değildir.

-Okur-yazarlık oranı ve doğuşta yaşam ümidi arttıkça, yoksulluk oranı düşmektedir. Bu nedenle, yoksulluğa karşı sosyal yatırım programlan önemli bir araç olarak gözükmektedir.

- Gini oranı düşük gelişmemiş ülkelerde, yoksulluk toplumca paylaşılmaktadır. Gini oranının yüksekliği, gelişmekte olan ülkelerde yoksulluğun artışını göstermektedir.

- İnsani Gelişmişlik İndeksi (HDI) yüksek olan ülkelerde, yoksulluk oranı düşüktür. Fakat bu her ülke için geçerli değildir (Dansuk, 1996: 44). 
Tablo 3: Küresel Gelir Farklılığı

\begin{tabular}{|c|c|c|c|c|}
\hline & $\begin{array}{c}\text { En yoksul } \\
\% 20\end{array}$ & $\begin{array}{c}\text { En zengin \% } \\
20\end{array}$ & $\begin{array}{c}\text { En zenginden } \\
\text { en yoksula }\end{array}$ & Gini Katsay1s1 \\
\hline 1960 & 2,3 & 70,2 & $30: 1$ & 0,69 \\
\hline 1970 & 2,3 & 73,9 & $32: 1$ & 0,71 \\
\hline 1980 & 1,7 & 76,3 & $45: 1$ & 0,79 \\
\hline 1989 & 1,4 & 82,7 & $59: 1$ & 0,87 \\
\hline
\end{tabular}

- Kaynak: UNDP; 1992.

Gelir dağılımındaki eşitsizlik uluslararası düzeyde, özellikle küreselleşme eğilimlerinin yoğunlaştığı dönemlerde oldukça kötüleşmiştir. Yukarıdaki tabloda da görüldüğü gibi, dönem içinde iki grup ülkenin ortalama gelirlerinin birbirine oran1 1960'ta 32:1'den 1989'da 59:1'e yükselmiştir.

\subsubsection{Türkiye Açısından Bir Analiz}

Küreselleşmenin Türkiye'de gelir bölüşümü ve yoksulluk oranı üzerine dolaylı etkisi hakkında bir fikir edinebilmek için, çeşitli değişkenler arasında regresyon analizi yapılmıştır. Yoksulluk verilerinin yetersiz oluşundan yola çıkılarak böyle bir analiz uygun görülmüştür. Yapılan analizler 1991-1998 dönemini kapsamaktır.

Analize satın alma paritesi ve kamu harcamaları arasındaki ilişkinin derecelendirilmesi ile başlanmıştır. Buna göre, satın alma paritesi ve kamu harcamaları arasında 0,998 oranında bir ilişki sıklığı (korelasyon katsayısı) mevcuttur. Bu ilişkinin varyasyonla açılanabilme derecesi ise, 0,996'dır. Satın alma paritesi ve kamu harcamaları için regresyon denklemi $\mathrm{Y}=$ $1867,919+0,0298 X$ X'dır. Burada, bağımsız değişken (X) kamu harcamaları; bağımlı değişken $(\mathrm{Y})$ ise satın alma paritesidir. Buna göre, kamu harcamalarındaki bir birimlik artış, satın alma paritesinde 0,0298'lik bir artışa neden olmaktadır. 
Sermaye girişleri ve satın alma paritesi arasındaki ilişkinin derecelendirilmesi ise şöyledir: Buna göre, sermaye girişleri ve satın alma paritesi arasında 0,999 oranında bir ilişki sıklığı (korelasyon katsayısı) vardır. Bu ilişkinin varyasyonla açıklanabilme derecesi ise, 0,998'dır. Sermaye girişleri ve satın alma paritesi için regresyon denklemi $\mathrm{Y}=$ $1684,287+0,01526 X^{\prime}$ 'dır. Burada, bağımsız değişken (X) sermaye girişleri; bağımlı değişken ( $\mathrm{Y}$ ) ise satın alma paritesidir. Buna göre, sermaye girişlerindeki bir birimlik artış, satın alma paritesinde $0,01526^{\prime}$ 'lik bir artışa neden olmaktadır.

Kamu harcamaları ve milli gelir arasındaki ilişkinin derecelendirilmesinde ise, kamu harcamaları ve milli gelir arasinda 0,925 oranında bir ilişki sıklığı (korelasyon katsayısı) vardır. $\mathrm{Bu}$ ilişkinin varyasyonla açılanabilme derecesi ise, $0,855^{\prime}$ dır. Kamu harcamaları ve milli gelir için regresyon denklemi $\mathrm{Y}=5440,462+0,0291 \mathrm{X}$ 'dır. Burada, bağımsız değişken (X) kamu harcamaları; bağımlı değişken $(\mathrm{Y})$ ise GSYIH'dır. Buna göre, kamu harcamalarında bir birimlik artış, GSYIH'da 0,0291'lik bir artışa neden olmaktadır.

Sermaye girişleri ve GSYIH arasında ise 0,911 oranında bir ilişki sıklığ 1 (korelasyon katsayısı) vardır. Bu ilişkinin varyasyonla açıklanabilme derecesi ise, 0,829'dur. Sermaye girişleri ve GSYİH için regresyon denklemi $\mathrm{Y}=5233,156+0,0000209 \mathrm{X}$ 'dır. Burada, bağımsız değişken $(\mathrm{X})$ sermaye girişleri; bağımlı değişken (Y) ise GSYİH'dir. Buna göre, sermaye girişlerindeki bir birimlik artış, GSYİH'da 0,0000209'luk bir artışa neden olmaktadır.

İhracat ve GSYIH arasında 0,942 oranında bir ilişki sıklığ (korelasyon katsayısı) olduğu görülmüştür $\mathrm{Bu}$ ilişkinin varyasyonla açıklanabilme derecesi ise, $0,887^{\prime}$ dur. İhracat ve GSYİH için regresyon denklemi $Y=$ $3348,319+0,118 X$ 'dır. Burada, bağımsız değişken (X) ihracat; bağımlı değişken (Y) ise GSYİH'dır. Buna göre, ihracattaki bir birimlik artış, GSYİH'da 0,0118'lik bir artışa neden olmaktadır.

Sermaye girişleri ve ihracat arasında 0,860 oranında bir ilişki sıklığı (korelasyon katsayısı) vardır. $\mathrm{Bu}$ ilişkinin varyasyonla açıklanabilme derecesi ise, 0,740 'dır. Sermaye girişleri ve ihracat için regresyon denklemi $Y=16474,165+0,000158 X^{\prime}$ dır. Burada, bağımsız değişken $(X)$ ihracat; bağımlı değişken ( $\mathrm{Y}$ ) ise sermaye girişleridir. Buna göre, ihracattaki bir birimlik artış, sermaye girişinde $0,000158^{\prime}$ lik bir artışa neden olmaktadır. 


\section{Yoksulluğa İlişkin Ekonomik-Sosyal Çözüm Önerileri}

Yoksullar arasındaki ilişki, ekonomik büyüme ve gelir dağılımı gibi konular, ekonomik kalkınma üzerine son zamanlardaki literatürde oldukça geniş ölçüde çalıșılmıştır. Toplam yoksulluğu hafifletebilecek en azından 2 şartın varlığı konusunda fikir birliği vardır. Illki, sağlam bir temel üzerine ekonomik büyümenin -veya gelir artışını- sağlanması zorunluluğudur. İkincisi, ekonomik büyümenin gelir dağllımı konusunda yansız olması gerektiğidir. Genel olarak, ekonomik büyüme gerçekleştirilemezse, yoksulluk azaltılamaz. Gerçekte, nüfusun önemli bir bölümünün sürekli yoksulluğu, ekonomik gelişme ümidini azaltabilir. Aynı zamanda, gelirin birincil dağılımı, yoksulluk hacminin azaltılmasına ve ekonomik büyüme ümitlerine büyük ölçüde etki edebilir. Oldukça eşitsiz gelir dağılımının, ekonomik büyümeye veya yoksulluğun azaltılmasına neden olmaması önemli bir kanıttır. Ekonomik büyümedeki son tecrübeler göstermiştir ki, eğer ülkeler sağlık ve eğitimin daha iyi olmasını sağlayacak tamamlayıcı ve teşvik edici yapılar geliştirirlerse, daha yüksek gelir sonucunu doğuracak, artan mevcut tüketim ve gelecekteki daha yüksek gelir yoluyla yoksullar iki kat fazla kazanç sağlayacaklardır (Khan, 2000: 26).

Yoksulluğun azaltılması, ekonomik büyümeyi gerektirir. Gelişmekte olan ülkeler ve geçiş ekonomileri için kişi başına reel gelir artışını muhafaza etmeyi başarmak hayati önemdedir. Üstelik ekonomik gelişme, yoksul kişiler için -kadınları da içerecek şekilde- gelir kazanımı firsatları yaratmalı ve yoksulların mal edinebilmesi için onlara geniş yol açmalıdır. Bunların ortaya çıkması için, ekonomi politikalarının doğru, dengeli ve koruyucu olması gerekmektedir. Yoksulluğun azaltılması aynı zamanda özellikle fakirler için temel sosyal hizmetlerdeki yatırımları da gerektirir. Ülkeler, yoksul kesime yüksek kaliteli ve maliyeti etkileyen (cost-effective) hizmetler vermeli ve kriz zamanlarında bu tür hizmetlerle sosyal güvenlik programlan sağlamalıdır. Diğer taraftan, yurt içi tasarruf oranlarını arttırıp, sınırlı kaynaklarını etkin programlar üzerinde akıllıca harcamalıdırlar (Gupta ve Diğ., 2000: 15).

Diğer taraftan, milli geliri yiyip bitiren yüksek nüfus artış hızının da kontrolü gerekmektedir. Nüfus artış hızı düşürülebilirse, gelişme hızlanacak ve hızlanan gelişme nüfus artış hızını daha aşağılara çekecektir. Az çocuklu ailelerin ekonomik ve sosyal açıdan desteklenmesi, çok çocuklu ailelere ise güçlükler çıkarılması yoluyla aile planlamasına gidilmesi bir çok ülkede başarılı sonuçlar vermiştir. Aynı zamanda kırsal kesimde sosyal güvenlik 
sistemleri geliştirerek, insanların yarınlarını garanti altına almak için çocuk sahibi olma yoluna gitmeleri önlenebilir.

Dünyada ve özellikle gelişmekte olan ülkelerde toplam kadın işgücünün çok az bir yüzdesi çalışmaktadır. Türkiye'de bu oran, $\% 30$ 'dur. Dolayısıyla kadın, ekonomiye entegre olmamıştır. Bu durumun iktisadi açıdan açılımı, oldukça büyük bir beşeri kaynak kaybını ifade etmektedir. Bu anlamda, sürdürülebilir kalkınmanın sağlanması ve yoksulluğun azaltılması açısından kadınlara yönelik programların çeşitlendirilmesi ve ekonomiye dahil edilmeleri gerekmektedir.

Yüksek gelirli ülkeler de sorumluluklarını yüklenmelidirler. Gelişmekte olan ülkelerden ithalat yapmak için tarifeleri ve diğer engelleri düşürmeli ve özellikle bunların nasıl etkili kullanılacağına ilişkin daha fazla yardım sağlamahdırlar. Çoğu OECD ülkesi bir hedef olarak milli gelirlerinin $\% 0.7$ 'si kadar yardım sağlanacağını kabul etmiş ama sadece birkaç ülke bu rakama ulaşmıştır (Gupta ve Diğ, 2000: 15).

\section{Sonuç ve Değerlendirme}

Küresel boyutta giderek artan ve yoğunlaşan yoksullaşma, süregeldiği ülkelerin sosyal dokularında önemli ölçüde gerilimler yaratmaktadır. Pek çok ülkede suç ve şiddet artmış; sosyal patlamalar, etnik çatışmalar kendini göstermiştir.

Çalışmada küresel boyutta görülen yoksullaşmanın özellikle 1980 sonrası derinleştiği görülmüştür. Özellikle gelişmekte olan ülkeler açısından, yoksulluğun tanımı değişmiştir. Eskiden yoksul olmak, işsiz olmak anlamına gelirken; artık yeterince tüketemiyor olmak yoksul anlamına gelmektedir. Yapısal uyum, küreselleşme gibi konularda gerekli ekonomik altyapı olmadan harekete geçen bu tür ülkelerde yoksulluk, IMF'nin yapısal uyum politikalarının hem nedeni hem de sonucu olarak ortaya çıkmaktadır. Ekonomik istikrarın sürekliliği, kaynak dağılımı ve gelir dağılımı işlevlerine bağlı olarak değişmektedir. $\mathrm{Bu}$ anlamda, kamu harcamaları komposizyonunun eğitime (özellikle kadınlar için), sağlığa ve yatırıma yönelmesi gerekmẹtedir.

Türkiye üzerine yapılan analizler sonucu, sermaye girişlerinin GSYİH'da oldukça az bir etkiye $(0,0000209)$ yol açtı̆̆ görülmektedir. Bu çerçevede, küreselleşmenin sermaye girişleri anlamında GSYİH'ya etkisi yok denecek 
kadar az olduğu söylenebilir. Kamu harcamaları ile milli gelir ilişkisi oldukça yüksektir. (analiz çerçevesinde) Kamu harcamalarının artışı, milli geliri \% 2'lik bir oranda etkilemektedir. Bu çerçevede, kamu harcamalarının üretime ve yatırıma yönelik olması önemlidir. Kamu harcamaları ise satın alma paritesini \% 2'lik oranda etkilemektedir. Satın alma gücünü etkileyen diğer oranlar arasında (analiz çerçevesinde) kamu harcamaları daha yüksek bir değere sahiptir. Diğer bir ifadeyle, kamu harcamaları satın alma gücünü etkileyen önemli faktörlerden birisidir.

$$
* * *
$$

\section{Summary}

The fact of increasing and dense poverty is one of the main problem for human beings. In addition to economic development, the fact should be minimized to prove social improvement.

For this aim in this study, after giving main criterion, the reason for the poverty is given seperately for the less developed, developing and developed countries and the effect of globalization on the fact of poverty is discussed. Then, spherical poverty is given generally, and the suggestions for the solution are given.

\section{Notlar}

${ }^{1}$ Gelirin tamamen eşit dağıtıldığı ideal ülkelerde hiç eşitsizlik olmayacağından bu katsayı, 0 olacaktır. Eşitsizlik arttıkça katsayı da büyüyecektir.

\section{Kaynaklar}

Ahmed Masood and Bredenkamp Hugh, "Supporting Poverty Reduction in Developing Countries", Finance and Development, December 2000.

Akalın, Güneri, Kamu Ekonomisi, Ankara, 
Akçar, Şengül, Yoksulluğu Önleme Stratejileri içinde "Kadın ve Yoksulluk", TESEV, İstanbul, 1998.

Aksu, Ömer A., Gelir ve Servet Dă̆ılımı, İstanbul, 1993.

Akyüz, Yılmaz, Sermaye, Bölüşüm, Büyüme, Ankara, 1980.

Bauman, Zygmunt (Çev: Ümit Öktem), Çalışma, Tüketicilik ve Yeni Yoksullar, Sarmal Yayınevi, İstanbul 1999.

Çağatay, Nilüfer ve Diğerleri, "Budgets As If People Mattered: Democratızıng Macroeconomic Policies", SEPED Conference Paper Series, May 2000.

Dansuk, Ercan, "Türkiye'de Yoksulluğun Ölçülmesi ve Sosyo-Ekonomik Yapılarla İlişkisi”, DPT Uzmanlık Tezi, Ankara Kasım 1996.

Demir, Osman, "Ekonomide Devlet", Sermaye Piyasası Kurulu, Yayın No:71, Mayıs 1997, Ankara.

Deepaklal and Myint, The Political Economy of Poverty, Equity and Growth, Clarendan Press, 1996.

Dumanlı, Recep,"Yoksulluk ve Türkiye'deki Boyutları", DPT Uzmanlık Tezi, Ankara, Haziran 1996.

Drucker, Peter F. (Çev: Birtane Karamakçı), Yeni Gerçekler, İş Bankası Yayınları, 1996, Ankara.

Dye, R. Thomas, Public Policy, Seventh Edition, 1992.

Erol,Ümit, Eleştirel Bir Gözle Serbest Piyasa, Bağlam Yayıncılık, 1997, İstanbul.

Gupta Sanjeev, Hammond Brian, Leete Richard and Swanson Eric, Progress Toward the International Development Goals, Finance \& Development, December 2000.

Gül, Songül Sallan ve Gül, Hüseyin, "Yoksulluk ve Yoksulluk Sorununa farklı Yaklaşımlar", Mülkiyeliler Birliği Dergisi, Cilt:XXI, Sayı:190. 
Khan, Mahmood Hasan, "Rural Poverty in Developing Countries", Finance\&Development, December 2000.

Lustig, Nora and Stern, Nicholas, "Broadening the Agenda for Poverty Reduction”, Finance\& Development, December 2000.

Martini, Pablo Rodas, "Income Inequality Withın and Between Countries: Main İssues in the Literature", Human Development Report 1999.

Prendergast, Renee and Steward, Frances (Çev: İdil Eser), Piyasa Güçleri ve Küresel Kalkınma, Yapı Kredi Yayınları, İstanbul, 1995.

Radikal Gazetesi, 25.9.2000, "Dünya Gelir Dağılımının da Çivisi Çıktı”, s.7

Smeeding, M.Timoty, "Financial Poverty in Developing Countries: The Evidence from The Luxembourg İncome Study", Human Development Papers, 1997.

Smith, Adam.(Çev: Ayşe Yunus, Mehmet Bakırc1), Ulusların Zenginliği, İstanbul, 1999.

UNDP 1992.

www.globalissues.org/TradeRelated/SAP.asp. 21.03.1997.

www.cbpp.org/index.html. 